\title{
Some Indicators of Nonspecific Immunity of Various Breeding Groups of Carp in Different Periods of the Annual Cycle
}

\author{
D. V. Mikryakove, *, G. I. Pronina ${ }^{b}$, T. A. Suvorova ${ }^{a}$, A. S. Sokolova ${ }^{a}$, \\ V. R. Mikryakov ${ }^{a}{ }^{\dagger}$, and A. B. Petrushin ${ }^{c}$ \\ ${ }^{a}$ Papanin Institute for the Biology of Inland Waters, Russian Academy of Sciences, Borok, Yaroslavl oblast, 152742 Russia \\ ${ }^{b}$ Russian State Agrarian University, Moscow Timiryazev Agricultural Academy, Moscow, 127550 Russia \\ ${ }^{c}$ All-Russia Research Institute of Integrated Fish Farming, Branch of the Ernst Federal Research Center for Animal Husbandry, \\ Vorovskogo, Borogodskii GO, Moscow oblast, 142460 Russia \\ *e-mail:daniil@ibiw.ru
}

Received July 3, 2020; revised November 17, 2020; accepted November 17, 2020

\begin{abstract}
A comparative study of some parameters of nonspecific immunity in the Angelinskii rubella-resistant variant of the scaly and mirror groups of carp in the prespawning and late feeding periods was carried out. The level of the antimicrobial properties of the $C$-reactive protein, nonspecific immune complexes in the blood serum, and phagocytic activity of neutrophils were studied. The study showed interbreed and inter-seasonal differences in some indicators. It is concluded that the higher level of bacteriostatic activity of blood serum in the rubella-resistant variant, compared with other groups of carp, provides a low percentage of immunodeficient individuals and resistance to pathogens of infectious diseases.
\end{abstract}

DOI: $10.1134 / \mathrm{S} 1062359021040105$

\section{INTRODUCTION}

The annual cycle of fish consists of a number of periods: prespawning, spawning, post-spawning, feeding, wintering migration, wintering, spawning migration, and prespawning feeding (Nikolsky, 1974). Earlier from the examples of the roach Rutilus rutilus, bream Abramis brama, river bass Perca fluviatilis, and blue bream Abramis ballerus, it was shown that the resistance of fish to bacterial infection in different periods of the year varies. During the spawning and post-spawning periods (May, June), a minimum resistance to the pathogens of aeromonosis of fish was noted, and the maximum resistance was at the end of the feeding period (Schaperclaus, 1979; Mikryakov, 1984).

During the spawning period, significant changes take place in the fish organism, requiring huge energy costs due to the activation of catabolic processes and reduction of anabolic processes. The metabolic processes include the structural fractions of lipids (phospholipids). The level of cholesterol increases, and that of albumin, glycogen, and $\alpha$-globulin decreases. During this period, the processes of dissimilation prevail over assimilation. Simultaneously, during the spawning and post-spawning periods, the proportion of individuals with a low level of immunoreactivity increases. During the feeding period, opposite pro-

\footnotetext{
${ }^{\dagger}$ Deceased.
}

cesses occur in the fish organism, which are associated with the restoration of the resources of plastic and energy substances expended during wintering and spawning and with an increase in the functional activity of the immune system (Shatunovsky, 1980; Mikryakov, 1984; Lloret et al., 2014).

The carp Cyprinus carpio grown on fish farms experiences fluctuations in the level of immunoreactivity during the annual cycle (Lysanov and Mikryakov 1990). A decrease in nonspecific immunity contributes to the creation of conditions for an outbreak of epizootics of infectious diseases. The spring period is considered the most dangerous. Fish experience stress as a result of capture, transportation, and changes in conditions of storage during their transfer from wintering grounds to feeding ponds. Exposure to stress factors leads to a decrease in survival, immunoreactivity, and nonspecific protection against pathogens of various infectious and invasive diseases (Wendelaar Bonga, 1997; Van Muiswinkel and Vervoorn-Van Der Wal, 2006; Uren Webster et al., 2018).

Rubella is considered one of the most common fish diseases causing great economic damage in the Russian Federation. This is a polyetiological disease of fish, mainly of the cyprinid family, the causative agents of which are the virus of spring viremia, aeromonas, and pseudomonas (Kirpichnikov et al., 1993; Golovina et al., 2003). To solve the problem of reducing significant damage to fish farming in Russia with 
the help of selection for immune resistance, the Angelinskii carp breed was bred, which is resistant to rubella pathogens (Ilyasov, 2002). The study of the indices of nonspecific immunity in rubella-resistant carp will make it possible to understand the mechanisms that ensure the immunity of fish to infectious diseases. Previously, the authors have shown differences in some immunobiochemical parameters between rubella-resistant carp and breeds susceptible to disease (Mikryakov et al., 2019a, 2019b; Suvorova et al., 2019). It was found that individuals of the rubellaresistant breed differ from carp of other breeding groups in the proportions of the content of various forms of leukocytes; the intensity of leukopoiesis; the level of protein, glucose, and total lipids; oxidative processes; and antioxidant protection. However, these data are insufficient to understand the peculiarities of the functioning of various body systems, including those responsible for the immune response and resistance to infectious diseases in specimens of the Angelinskii breed.

The purpose of this work is a comparative study of the indicators of nonspecific immunity of rubellaresistant fish with carp, which is receptive to rubella pathogens.

\section{MATERIALS AND METHODS}

Carp 2+ to 3+ years of age were studied in May and September 2018 during the transfer of fish from wintering grounds to feeding ponds, and vice versa. The material was taken from specimens of the Angelinskii scaly rubella-resistant breed kept at the Sunoga experimental pond base at the Papanin Institute for the Biology of Inland Waters, Russian Academy of Sciences, Yaroslavl oblast. For comparison, we used scaly and mirror carp susceptible to rubella pathogens from the Kirya fish farm of the Chuvash Republic.

In fish, blood was taken from the tail vein to study the bacteriostatic blood serum activity (BAS), the proportion of immunodeficient (IMD) individuals, the content of nonspecific immune complexes (IC), the level of the $C$-reactive protein (CRP), and the phagocytic activity (PA) of neutrophils. To determine PA, smears were made, which were fixed in a $5 \%$ solution of sulfosalicylic acid for 60-90 s, washed with distilled water, dried, and then stained with a $0.1 \%$ solution of bromophenol blue in borate buffer for 1-2 minutes. Then, they were washed three times with a $0.05 \mathrm{M}$ borate buffer solution for $1-3 \mathrm{~min}$. At the next stage, the nuclei were supplemented with $1 \%$ safranin solution for 30-60 s. To obtain serum, fish blood was collected in a dry sterile test tube. The test tube with blood was left in a rack for $1 \mathrm{~h}$ at room temperature, and then kept for 1 day in a refrigerator at $4^{\circ} \mathrm{C}$ for blood coagulation and clot retraction. After that, the serum was taken with a syringe with a fine needle and transferred into an Eppendorf tube. The samples were frozen in a freezer at a temperature of -18 to $-20^{\circ} \mathrm{C}$ and transported in special thermal containers. In the laboratory, immediately before analysis, samples were thawed at room temperature.

BAS was assessed by the nephelometric method according to the modification by Mikryakov (1984). Depending on the level of BAS, the proportion of IMD was revealed in individuals whose blood serum did not inhibit the development of test microbes. The CRP level was determined visually by the agglutination reaction of the latex reagent with blood serum using the CRP-Olvex reagent kit. The IR content was established spectrophotometrically at a wavelength of $450 \mathrm{~nm}$ by the method of selective precipitation with a $4 \%$ polyethylene glycol molecular mass of 6000 as recommended earlier (Grinevich and Alferov, 1981). Spectrophotometric studies were carried out using a KFK-3 photoelectric photometer of the Zagorsk Optical and Mechanical Plant. PA was determined by the content of non-enzymatic cationic protein in lysosomes of peripheral blood neutrophils by the cytochemical method with bromophenol blue (Shubich, 1974), adapted for aquatic organisms. Microscopic examination of smears was performed under an Optika DM-15 digital microscope with magnification $(\times 600)$, looking at 100 cells in each smear. According to the degree of phagocytic activity, the cells under study were divided into four groups $(0-3$ points): 0 , there are no cationic protein granules; 1 , single granules; 2, granules occupy $\sim 1 / 4$ of the cytoplasm; 3 , granules occupy more than $1 / 4$ of the cytoplasm. The average cytochemical coefficient (ACC) was calculated using the following formula:

$$
\text { ACC }=\left(0 \times \mathrm{H}_{0}+1 \times \mathrm{H}_{1}+2 \times \mathrm{H}_{2}+3 \times \mathrm{H}_{3}\right) / 100,
$$

where $\mathrm{H}_{0}, \mathrm{H}_{1}, \mathrm{H}_{2}$, and $\mathrm{H}_{3}$ are respectively, the number of neutrophils with an activity of $0,1,2$ and 3 points;

$$
\mathrm{H}_{0}+\mathrm{H}_{1}+\mathrm{H}_{2}+\mathrm{H}_{3}=100 \text {. }
$$

Statistical processing of the results was carried out according to standard algorithms implemented in the Statistica V6.0 software package using the $t$-test. The differences were considered significant at $p \leq 0.05$.

\section{RESULTS AND DISCUSSION}

Comparative analysis showed that individuals of the rubella-resistant breed and others breeding groups of the carp Cyprinus carpio had inter-seasonal and interbreed differences in the parameters studied (Table 1).

It is known that BAS is an integral indicator of the functional state of innate factors of humoral immunity: complement systems, lysozyme, immunoglobulins, antimicrobial peptides, lectins, precipitins, $\beta$-lysine, properdin, defensin, etc. (Mikryakov, 1984; Royt et al., 2000; Van Muiswinkel and Vervoorn-Van der Wal, 2006; Koiho et al., 2008; Van der Marel, 2012; Campoverde et al., 2017; etc.). The BAS value was several times higher in carp caught in autumn compared to spring, while in rubella-resistant species 
Table 1. Indicators of nonspecific immunity of carp

\begin{tabular}{l|c|c|c}
\hline \multicolumn{1}{c|}{ Indicator } & Angelinskii carp & Scaly carp & Mirror carp \\
\hline Number of fish & $\frac{5}{6}$ & $\frac{10}{8}$ & $\frac{10}{8}$ \\
\hline Body weight, g & $\frac{284.40 \pm 12.37}{863.00 \pm 34.41}$ & $\frac{241.77 \pm 22.41}{2022.37 \pm 69.70}$ & $\frac{270.20 \pm 22.94}{2033.75 \pm 71.05}$ \\
\hline Body length, cm & $\frac{22.74 \pm 0.19}{32.35 \pm 0.51}$ & $\frac{22.09 \pm 0.75}{42.66 \pm 0.54}$ & $\frac{23.04 \pm 0.61}{40.41 \pm 0.40}$ \\
\hline Bacteriostatic activity of blood serum, \% & $\frac{23.22 \pm 6.54}{53.93 \pm 5.26^{*}}$ & $\frac{7.10 \pm 6.34^{\mathrm{a}}}{58.77 \pm 15.01^{*}}$ & $\frac{5.16 \pm 2.18^{\mathrm{a}}}{45.40 \pm 14.40^{*}}$ \\
\hline Immunodeficient individuals, \% & $\frac{20}{0}$ & $\frac{70}{25}$ & $\frac{60}{25}$ \\
\hline $\begin{array}{l}\text { Immune complexes, conv. units } \\
\text { C-reactive protein, mg/L }\end{array}$ & $\frac{1.82 \pm 0.70}{1.50 \pm 0.54}$ & $\frac{1.25 \pm 0.46}{1.00 \pm 0.27}$ & $\frac{0.94 \pm 0.21}{1.21 \pm 0.37}$ \\
\hline $\begin{array}{l}\text { Average cytochemical coefficient of lysosomal } \\
\text { cationic protein in blood neutrophils, units }\end{array}$ & $\frac{1.78 \pm 0.10}{1.60 \pm 0.06}$ & $\frac{1.88 \pm 0.04}{1.84 \pm 0.04}$ & $\frac{>6}{>6}$ \\
\hline
\end{tabular}

Above the line are spring indicators, and below the line are autumn indicators; $*$ denotes significant differences between spring and autumn indicators; ${ }^{\text {a }}$ significant differences between the Angelinskii breed and other groups (scaly and mirror) carp, with $p \leq 0.05$.

the inter-seasonal differences were not as significant as in scaly and mirror carp. As mentioned above, such differences are associated with the level of the functional state of the immune system of the fish organism in different periods of the annual cycle. A similar change in the BAS level was recorded for ecologically different species of fish: the burbot Lota lota, blue bream Abramis ballerus, roach Rutilus rutilus, and bream Abramis brama (Mikryakov and Silkin, 1978; Mikryakov, 1984).

Comparison of the level between different breeding groups showed that the spring BAS indices in individuals of the rubella-resistant variant were 3.3 times higher than in scaly carp and 4.5 times higher than in mirror carp. A low level of BAS is associated with a high percentage of IMD of individuals among scaly and mirror carp. In the Angelinskii breed, the percentage of such individuals was low even in the spring, which indicates a higher level functional state of nonspecific humoral immunity.

The study of the IC content showed insignificant differences among the groups of fish studied. Higher rates were recorded in the spring (with the exception of mirror carp). It is known that ICs, antigen-antibody complexes and the associated complementary components, formed as a result of the interaction with low molecular weight foreign compounds (haptens, soluble antigens, and autoantigens). They play an important role in the regulation of immune responses, the elimination of xenobiotics from the body, and the maintenance of immunological and biochemical homeostasis. When the organism is saturated with foreign bodies, excessive formation of ICs occurs due to suppression of the clearing function of cells of the phagocytic system (Loginov et al., 1999; Coico et al., 2008). The absence of significant interspecies and inter-seasonal differences in the level of ICs in the blood serum indicates a good content of the carp and the absence of infectious agents. Inter-seasonal changes are probably associated with the intensity of accumulation and utilization of ICs by the fish organism.

Study of the level of CRP, the acute phase protein, the most sensitive laboratory marker of infection, inflammation, and tissue damage, showed off-season differences in Angelinskii carp and scaly carp. A weakly positive level of CRP $(6 \mathrm{mg} / \mathrm{L})$ was recorded in rubella-resistant carp in spring and in scaly carp in autumn. The rest of the samples showed a positive result (more than $6 \mathrm{mg} / \mathrm{L}$ ). CRP, one of the key components of humoral innate immunity, provides a connection between the innate and adaptive immune systems (Nazarov, 2010), capable of recognizing microbes and promoting their absorption by phagocytes (Bottazzi et al., 2010; Lee et al., 2017). CRP is a very sensitive element in the blood, reacting faster than others to tissue damage. In the serum of a healthy organism, CRP is absent, but its level increases rapidly and many times in infectious and parasitic diseases. The low content of CRP in the body of the rubella- 
resistant carp breed in spring is probably related to the high level of BAS.

Phagocytes are capable of killing pathogens using a variety of mechanisms, which can be broadly classified as oxygen-dependent or oxygen-independent. Studies have shown that monocytes/macrophages and granulocytes (neutrophils and, in some cases, eosinophils) have phagocytic activity in fish. Granulocytes (especially neutrophils) are mobile, phagocytic cells that produce reactive oxygen species, but their bactericidal activity is lower than macrophages (Hoar et al., 1996). The results of the lysosomal cation test showed that the potential phagocytic activity of neutrophils in fish blood was within the physiological norm for carp of this age category. However, in autumn, a significant decrease in the ACC of the cationic protein was noted in the mirror group of carp. Such a decrease in the autumn period indicates the expenditure of a highly toxic lysosomal cationic protein in the process of nonspecific cellular immune defense (phagocytosis) in fish during the foraging period. Similar results were obtained by us earlier (Pronina et al., 2019) and indicate a good immune status of fish during this period of the year.

Study of the immunological parameters in the rubella-resistant variant of the carp Cyprinus carpio made it possible to obtain new data on the level of nonspecific immunity in the spring and autumn periods of the annual cycle. The analysis of the data obtained showed the interseasonal and interbreed differences of the parameters studied. The most significant differences were recorded in the level of BAS and the number of IMD of individuals in the spring. A high level functional state of nonspecific humoral immunity, in particular the bacteriostatic properties of blood serum, probably provides immunity to carp of the Angelinskii breed against the causative agents of rubella. The data obtained can be used as markers when carrying out selection and breeding work to increase the resistance of fish to infectious diseases.

\section{FUNDING}

This work was supported by the Russian Foundation for Basic Research (project no. 18-016-0019618) and in part within the framework of a State Assignment (topic no. AAAA-A18-118012690123-4).

\section{COMPLIANCE WITH ETHICAL STANDARDS}

Conflict of interest. The authors declare that they have no conflict of interest.

Statement on the welfare of animals. All applicable international, national, and/or institutional guidelines for the care and use of animals were followed.

\section{OPEN ACCESS}

This article is licensed under a Creative Commons Attribution 4.0 International License, which permits use, sharing, adaptation, distribution and reproduction in any medium or format, as long as you give appropriate credit to the original author(s) and the source, provide a link to the Creative Commons licence, and indicate if changes were made. The images or other third party material in this article are included in the article's Creative Commons licence, unless indicated otherwise in a credit line to the material. If material is not included in the article's Creative Commons licence and your intended use is not permitted by statutory regulation or exceeds the permitted use, you will need to obtain permission directly from the copyright holder. To view a copy of this licence, visit http://creativecommons.org/licenses/by/4.0/.

\section{REFERENCES}

Bottazzi, B., Doni, A., Garlanda, C., and Mantovani, A., An integrated view of humoral innate immunity: pentraxins as a paradigm, Ann. Rev. Immunol., 2010, vol. 28, pp. 157183.

Campoverde, C., Milne, D.J., Estevez, A., Duncan, N., Secombes, C.J., and Andree, K.B., Ontogeny and modulation after PAMPs stimulation of $\beta$-defensin, hepcidin, and piscidin antimicrobial peptides in meagre (Argyrosomus regius), Fish Shellfish Immunol., 2017, vol. 69, pp. 200-210.

Coico, R., Sunshine, G., and Benjamin, E., Immunology: A Short Course, New York: Wiley, 2003, 5th ed.

Golovina, N.A., Strelkov, Yu.A., Voronin, V.N., Golovin, P.P., Evdokimova, E.B., and Yukhimenko, L.N., Ikhtiopatologiya (Ichthyopathology), Golovina, N.A. and Bauer, O.N., Eds., Moscow: Mir, 2003.

Grinevich, Yu.A. and Alferov, A.N., Determination of immune complexes in the blood of cancer patients, Lab. Delo, 1981, no. 8, pp. 493-496.

Hoar, W.S., Randall, D.J., Iwama, G., and Nakanishi, T., The fish immune system: organism, pathogen, and environment, in Fish Physiology, San Diego, California: Academic, 1996, vol. 15.

Ilyasov, Yu.I., Selection of fishes for increasing resistance to diseases, in Aktual'nye voprosy presnovodnoi akvakul'tury (Actual Problems of Freshwater Aquaculture), Moscow: VNIRO, 2002, issue 78, pp. 125-134.

Kirpichnikov, V.S., Ilyasov, Ju.I., Shart, L.A., Vikhman, A.A., Ganchenko, M.V., Ostashevsky, A.L., Simonov, V.M., Tikhonov, G.F., and Tjurin, V.V., Selection of Krasnodar common carp (Cyprinus carpio L.) for resistance to dropsy: principal results and prospects, Aquaculture, 1993, vol. 111, pp. 7-20.

Lee, P.T., Bird, S., Zou, J., and Martin, S.A.M., Phylogeny and expression analysis of C-reactive protein (CRP) and serum amyloid-P (SAP) like genes reveal two distinct groups in fish, Fish Shellfish Immunol., 2017, vol. 65, pp. 42-51.

Lloret, J., Shulman, G., and Love, R.M., Condition and Health Indicators of Exploited Marine Fishes, Wiley Blackwell, 2014, p. 247.

Loginov, S.I., Smirnov, P.N., and Trunov, A.N., Immunnye kompleksy u zhivotnykh i cheloveka: norma i patologiya (Immune Complexes in Animals and Humans: Norm and $\mathrm{Pa}-$ 
thology), Novosibirsk: RASKhN, Sib. Otd. IEVS i DV, 1999.

Lysanov, A.V. and Mikryakov, V.R., Features of the seasonal dynamics of total protein and bacterioagglutinins in carp (Cyprinus carpio L.) in a warm-water fishery, Biol. Vnutr. Vod: Inform. Byull., 1990, no. 86, pp. 49-51.

Van der Marel, M.C., Carp mucus and its role in mucosal defense, Ph.D. Thesis, The Netherlands: Wageningen Univ., 2012.

Mikryakov, V.R., Patterns of the functioning of the immune system of freshwater fishes, Extended Abstract of Doctoral (Biol.) Dissertation, Moscow: Inst. Evol. Morfol. Ekol. Zhiv., Akad. Nauk SSSR, 1984.

Mikryakov, V.R. and Silkin, N.F., Seasonal dynamics of antimicrobial properties of blood serum in fish species of different ecology, Biol. Vnutr. Vod: Inform. Byull., 1978, no. 39, pp. 63-68.

Mikryakov, D.V., Pronina, G.I., Suvorova, T.A., Sokolova, A.S., Petrushin, A.B., and Kuz'micheva, S.V., The content of immune complexes and total lipids and the oxidative processes in the immunocompetent organs of the aeromonasisresistant carp breed at the end of the feeding period, $R y$ bovod. Rybn. Khoz., 2019a, no. 8, pp. 49-55.

Mikryakov, D.V., Revyakin, A.O., Pronina, G.I., Sokolova, A.S., Mikryakov, V.R., and Petrushin, A.B., Biochemical parameters of blood serum of aeromonasis-resistant carp breed after wintering, Tr. Inst. Biol. Vnutr. Vod im. I.D. Papanina, Ross. Akad. Nauk, 2019b, no. 87 (90), pp. 56-61.

Van Muiswinkel, W. and Vervoorn-Van Der Wal, B., The immune system of fish, Fish Dis. Disord., 2006, vol. 1, pp. 678-701.
Nazarov, P.G., Pentraxins in the reactions of innate and acquired immunity, matrix organization, and fertility, Med. Akad. Zh., 2010, vol. 10, no. 4, pp. 107-124.

Nikol'skii, G.V., Ekologiya ryb (Fish Ecology), Moscow: Vysshaya shkola, 1974.

Pronina, G.I., Petrushin, A.B., Shishanova, E.I., and Rozumnaya, L.A., Physiological and immunologic peculiarities of the "surskiy malokostniy" immune resistant carp cross, J. Aquat. Sci., 2019, vol. 10, no. 2, pp. 83-87.

Roitt, I.M., Brostoff, J., and Male, D.K., Immunology, London: Mosby, 1998, 5th ed.

Schaperclaus, W., Fischkrankheiten, Berlin: Academic, 1979, vol. 1.

Shatunovskii, M.I., Ekologicheskie zakonomernosti obmena veshchestv morskikh ryb (Ecological Patterns of Metabolism of Marine Fishes), Moscow: Nauka, 1980.

Shubich, M.G., Detection of cationic protein in the cytoplasm of leukocytes using bromophenol blue, Tsitologiya, 1974, no. 10, pp. 1321-1322.

Suvorova, T.A., Pronina, G.I., Mikryakov, D.V., and Petrushin, A.B., Composition of peripheral blood leukocytes and immunocompetent organs of the aeromonasis-resistant carp breed at the end of the feeding period, Aktual. Vopr. Vet. Biol., 2019, no. 3 (43), pp. 25-29.

Uren Webster, T.M., Rodriguez-Barreto, D., Martin, S.A.M., van Oosterhout, C., Orozco-terWengel, P., Cable, J., Hamilton, A., Garcia de Leaniz, C., and Consuegra, S., Contrasting effects of acute and chronic stress on the transcriptome, epigenome, and immune response of Atlantic salmon, Epigenetics, 2018, vol. 13, no. 12, pp. 1191-1207.

Wendelaar Bonga, S.E., The stress response in fish, Physiol. Rev., 1997, vol. 77, no. 3, pp. 591-625. 